\title{
Perceived Stress and its' Association with College Students
}

\author{
Sangya Singh* \\ Pantnagar, U. S. Nagar, Uttarakhand, India \\ *Corresponding author
}

\section{Keywords}

Perceived stress, Disrupted,

Homeostasis,

Neuroendocrine

Article Info

\section{Accepted:}

12 March 2021

Available Online:

10 April 2021

\section{A B S T R A C T}

Stress refers to the perceived or actual threat on physical and/or psychological homeostasis of the human body. Disrupted homeostasis elicits the so called "stress response", meaning the activation of central and peripheral neuroendocrine mechanisms responsible for various adaptive responses and behaviors. PSS was originally developed as a 14-item scale that assess the perception of stressful experiences by asking the respondent to rate the frequency of his/her feelings and thoughts related to events and situations that occurred over the previous month. Stress mainly refers to the perceived or actual threat to the physical and/or psychological homeostasis of the human body. The stress-reduction approach based on mindfulness practices has recently enjoyed an explosion of interest from a variety of healthcare and epidemiological researchers. Disrupted homeostasis elicits the so-called "stress response", meaning the activation of central and peripheral neuroendocrine mechanisms responsible for various adaptive responses and behaviors. The purpose of this study was to measure the level of perceived stress among the students of Post Graduation. The study used a convenience sample of female and male college students. A scale for measuring the perceived stress level was adopted. PSS assesses the perception of stressful experiences by asking the respondent to rate the frequency of his/her feelings and thoughts related to events and situations that occurred over the previous month to collect data from the respondents. The majority of the respondents agreed that they often perceived stress because of something that happened unexpectedly in the last month, they were unable to control the important things in their life, they were not confident enough to handle their problems or being unable to control irritations, etc. Students often perceived stress when things were out of their control or they found it difficult to pile the things up because of uncontrollable situations. 


\section{Introduction}

Stress, or to be more accurate pressure, is an unavoidable part of everyday life, meaning different things to each of us. Stress is much more recognized than it used to be, we have become very aware of the potential negative impact of stress on our health. Yet despite all of this information and wealth of knowledge, the subject of stress still remains vague and not very well understood. There are also many myths about stress that are not accurate and this further confuses the subject. Life in the $21^{\text {st }}$ Century is infinitely far more complex than it has ever been. We were never designed to live in this complex, modern world with its many demands on us. We live in a crowded, noisy society that we often refer to as the rat race. Our lives are run by deadlines, the clock, modern technology, mobile phones, pagers, faxes, computers, satellites and a hundred and one other demands and pressures.

\section{Materials and Methods}

An effective research methodology is grounded in the overall approach of the study - whether qualitative or quantitative - and adequately describes the methods the researcher used in the study. It is a body of methods, rules, and postulates employed by a discipline : a particular procedure or set of procedures.

\section{Perceived Stress Scale}

This scale was developed by Sheldon Cohen. The Perceived Stress Scale (PSS) is the most widely used psychological instrument for measuring the perception of stress. It is a measure of the degree to which situations in one's life are appraised as stressful. It is a four point scale developed to identify the respondent's feelings and thoughts during the last month. The following points were assigned to the respondents depending on their responses:
Very often - 4

Fairly often - 3

Sometimes - 2

Almost Never - 1

Never - 0

The overall occurrence of perceived level of stress among the respondents were calculated through excluded method of quantitative classification in which each was categorized into the following scores :

\section{Results and Discussion}

Stress is a feeling of emotional or physical tension. It can come from any event or thought that makes you feel frustrated, angry, or nervous.

Stress is your body's reaction to a challenge or demand. In short bursts, stress can be positive, such as when it helps you avoid danger or meet a deadline. So, in order to know the level of perceived stress among female and male students, this scale was developed.

\section{Perceived Stress Scale}

This scale was developed by Sheldon Cohen in the year 1983. The Perceived Stress Scale is the mostly used instrument to measure the perception of stress and also to keep an account of the things that are happening in their life. This scale is a measure of the degree at which anyone's life situations are appraised as stressful. Results of the table shows that very few female respondents perceived stress never. Only a few respondents ranging from two to eight per cent of the respondents reported that they almost never perceived stress. 
Table.1

\begin{tabular}{|c|c|c|}
\hline S. No. & Score & Category \\
\hline $\mathbf{1}$ & $0-10$ & Very often \\
\hline $\mathbf{2}$ & $11-20$ & Fairly often \\
\hline $\mathbf{3}$ & $21-30$ & Sometimes \\
\hline $\mathbf{4}$ & $31-40$ & Almost never \\
\hline $\mathbf{5}$ & $41-50$ & Never \\
\hline
\end{tabular}

Table.2 Perceived Stress among Female Respondents

\begin{tabular}{|c|c|c|c|c|c|c|}
\hline \multicolumn{7}{|c|}{ PERCEIVED STRESS SCALE (FEMALE) } \\
\hline $\begin{array}{l}\text { S. } \\
\text { No. }\end{array}$ & PERCIEVED STRESS & NEVER & $\begin{array}{l}\text { ALMOST } \\
\text { NEVER }\end{array}$ & SOMETIMES & $\begin{array}{l}\text { FAIRLY } \\
\text { OFTEN }\end{array}$ & $\begin{array}{l}\text { VERY } \\
\text { OFTEN }\end{array}$ \\
\hline $\mathbf{1}$ & $\begin{array}{c}\text { In the last month, how often have } \\
\text { you been upset because of } \\
\text { something that happened } \\
\text { unexpectedly? }\end{array}$ & $\begin{array}{c}2 \\
(3.34)\end{array}$ & $\begin{array}{c}6 \\
(10)\end{array}$ & $\begin{array}{c}13 \\
(21.67)\end{array}$ & $\begin{array}{c}26 \\
(43.34)\end{array}$ & $\begin{array}{c}14 \\
(23.34)\end{array}$ \\
\hline 2 & $\begin{array}{l}\text { In the last month, how often have } \\
\text { you felt that you were unable to } \\
\text { control the important things in } \\
\text { your life? }\end{array}$ & $\begin{array}{c}1 \\
(1.67)\end{array}$ & $\begin{array}{c}4 \\
(6.67)\end{array}$ & $\begin{array}{c}18 \\
(30)\end{array}$ & $\begin{array}{c}18 \\
(30)\end{array}$ & $\begin{array}{c}19 \\
(31.67)\end{array}$ \\
\hline 3 & $\begin{array}{l}\text { In the last month, how often have } \\
\text { you felt nervous and "stressed"? }\end{array}$ & $\begin{array}{c}1 \\
(1.67)\end{array}$ & $\begin{array}{c}8 \\
(13.34)\end{array}$ & $\begin{array}{c}14 \\
(23.34)\end{array}$ & $\begin{array}{c}21 \\
(35)\end{array}$ & $\begin{array}{c}16 \\
(26.67)\end{array}$ \\
\hline 4 & $\begin{array}{c}\text { In the last month, how often have } \\
\text { you felt confident about your } \\
\text { ability to handle your personal } \\
\text { problems? }\end{array}$ & $\begin{array}{c}2 \\
(3.34)\end{array}$ & $\begin{array}{c}8 \\
(13.34)\end{array}$ & $\begin{array}{c}25 \\
(41.67)\end{array}$ & $\begin{array}{c}11 \\
(18.34)\end{array}$ & $\begin{array}{c}14 \\
(23.34)\end{array}$ \\
\hline 5 & $\begin{array}{c}\text { In the last month, how often have } \\
\text { you felt that things were going } \\
\text { your way? }\end{array}$ & $\begin{array}{c}3 \\
(5)\end{array}$ & $\begin{array}{c}6 \\
(10)\end{array}$ & $\begin{array}{c}19 \\
(31.67)\end{array}$ & $\begin{array}{c}21 \\
(35)\end{array}$ & $\begin{array}{c}11 \\
(18.34)\end{array}$ \\
\hline 6 & $\begin{array}{l}\text { In the last month, how often have } \\
\text { you found that you could not cope } \\
\text { with all the things that you had to } \\
\text { do? }\end{array}$ & $\begin{array}{c}4 \\
(6.67)\end{array}$ & $\begin{array}{c}3 \\
(5)\end{array}$ & $\begin{array}{c}11 \\
(18.34)\end{array}$ & $\begin{array}{c}24 \\
(40)\end{array}$ & $\begin{array}{c}18 \\
(30)\end{array}$ \\
\hline 7 & $\begin{array}{l}\text { In the last month, how often have } \\
\text { you been able to control irritations } \\
\text { in your life? }\end{array}$ & $\begin{array}{c}2 \\
(3.34)\end{array}$ & $\begin{array}{c}8 \\
(13.34)\end{array}$ & $\begin{array}{c}17 \\
(28.34)\end{array}$ & $\begin{array}{c}22 \\
(36.67)\end{array}$ & $\begin{array}{c}11 \\
(18.34)\end{array}$ \\
\hline 8 & $\begin{array}{l}\text { In the last month, how often have } \\
\text { you felt that you were on top of } \\
\text { things? }\end{array}$ & $\begin{array}{c}3 \\
(5)\end{array}$ & $\begin{array}{c}2 \\
(3.34)\end{array}$ & $\begin{array}{c}10 \\
(16.67)\end{array}$ & $\begin{array}{c}30 \\
(50)\end{array}$ & $\begin{array}{c}15 \\
(25)\end{array}$ \\
\hline 9 & $\begin{array}{c}\text { In the last month, how often have } \\
\text { you been angered because of } \\
\text { things that were outside of your } \\
\text { control? }\end{array}$ & $\begin{array}{c}1 \\
(1.67)\end{array}$ & $\begin{array}{c}7 \\
(28.34)\end{array}$ & $\begin{array}{c}12 \\
(20)\end{array}$ & $\begin{array}{c}22 \\
(36.67)\end{array}$ & $\begin{array}{c}18 \\
(30)\end{array}$ \\
\hline 10 & $\begin{array}{l}\text { In the last month, how often have } \\
\text { you felt difficulties were piling up } \\
\text { so high that you could not } \\
\text { overcome them? }\end{array}$ & $\begin{array}{c}2 \\
(3.34)\end{array}$ & $\begin{array}{c}5 \\
(8.34)\end{array}$ & $\begin{array}{c}10 \\
(16.67)\end{array}$ & $\begin{array}{c}25 \\
(41.67)\end{array}$ & $\begin{array}{c}18 \\
(30)\end{array}$ \\
\hline
\end{tabular}


Table.3 Perceived Stress among Male Respondents

\begin{tabular}{|c|c|c|c|c|c|c|}
\hline \multicolumn{7}{|c|}{ PERCEIVED STRESS SCALE (MALE) } \\
\hline $\begin{array}{l}\text { S. } \\
\text { No. }\end{array}$ & PERCIEVED STRESS & NEVER & $\begin{array}{l}\text { ALMOST } \\
\text { NEVER }\end{array}$ & SOMETIMES & $\begin{array}{l}\text { FAIRLY } \\
\text { OFTEN }\end{array}$ & $\begin{array}{l}\text { VERY } \\
\text { OFTEN }\end{array}$ \\
\hline 1 & $\begin{array}{l}\text { In the last month, how } \\
\text { often have you been } \\
\text { upset because of } \\
\text { something that happened } \\
\text { unexpectedly? }\end{array}$ & $\begin{array}{c}1 \\
(1.67)\end{array}$ & $\begin{array}{c}2 \\
(3.34)\end{array}$ & $\begin{array}{c}15 \\
(25)\end{array}$ & $\begin{array}{c}21 \\
(35)\end{array}$ & $\begin{array}{c}21 \\
(35)\end{array}$ \\
\hline 2 & $\begin{array}{l}\text { In the last month, how } \\
\text { often have you felt that } \\
\text { you were unable to } \\
\text { control the important } \\
\text { things in your life? }\end{array}$ & $\begin{array}{c}2 \\
(3.34)\end{array}$ & $\begin{array}{c}7 \\
(11.67)\end{array}$ & $\begin{array}{c}14 \\
(23.34)\end{array}$ & $\begin{array}{c}23 \\
(38.34)\end{array}$ & $\begin{array}{c}14 \\
(23.34)\end{array}$ \\
\hline 3 & $\begin{array}{l}\text { In the last month, how } \\
\text { often have you felt } \\
\text { nervous and "stressed"? }\end{array}$ & $\begin{array}{c}2 \\
(3.34)\end{array}$ & $\begin{array}{c}7 \\
(11.67)\end{array}$ & $\begin{array}{c}11 \\
(18.34)\end{array}$ & $\begin{array}{c}12 \\
(20)\end{array}$ & $\begin{array}{c}28 \\
(46.67)\end{array}$ \\
\hline 4 & $\begin{array}{l}\text { In the last month, how } \\
\text { often have you felt } \\
\text { confident about your } \\
\text { ability to handle your } \\
\text { personal problems? }\end{array}$ & $\begin{array}{c}1 \\
(1.67)\end{array}$ & $\begin{array}{c}16 \\
(26.67)\end{array}$ & $\begin{array}{c}22 \\
(36.67)\end{array}$ & $\begin{array}{c}15 \\
(25)\end{array}$ & $\begin{array}{c}6 \\
(10)\end{array}$ \\
\hline 5 & $\begin{array}{l}\text { In the last month, how } \\
\text { often have you felt that } \\
\text { things were going your } \\
\text { way? }\end{array}$ & $\begin{array}{c}3 \\
(5)\end{array}$ & $\begin{array}{c}9 \\
(15)\end{array}$ & $\begin{array}{c}19 \\
(31.67)\end{array}$ & $\begin{array}{c}18 \\
(30)\end{array}$ & $\begin{array}{c}11 \\
(18.34)\end{array}$ \\
\hline 6 & $\begin{array}{l}\text { In the last month, how } \\
\text { often have you found } \\
\text { that you could not cope } \\
\text { with all the things that } \\
\text { you had to do? }\end{array}$ & $\begin{array}{c}2 \\
(3.34)\end{array}$ & $\begin{array}{c}6 \\
(10)\end{array}$ & $\begin{array}{c}7 \\
(11.67)\end{array}$ & $\begin{array}{c}24 \\
(40)\end{array}$ & $\begin{array}{c}21 \\
(35)\end{array}$ \\
\hline 7 & $\begin{array}{c}\text { In the last month, how } \\
\text { often have you been able } \\
\text { to control irritations in } \\
\text { your life? }\end{array}$ & $\begin{array}{c}4 \\
(6.67)\end{array}$ & $\begin{array}{c}11 \\
(18.34)\end{array}$ & $\begin{array}{c}16 \\
(26.67)\end{array}$ & $\begin{array}{c}10 \\
(16.67)\end{array}$ & $\begin{array}{c}19 \\
(31.67)\end{array}$ \\
\hline 8 & $\begin{array}{l}\text { In the last month, how } \\
\text { often have you felt that } \\
\text { you were on top of } \\
\text { things? }\end{array}$ & $\begin{array}{c}2 \\
(3.34)\end{array}$ & $\begin{array}{c}5 \\
(8.34)\end{array}$ & $\begin{array}{c}10 \\
(16.67)\end{array}$ & $\begin{array}{c}26 \\
(43.34)\end{array}$ & $\begin{array}{c}17 \\
(28.34)\end{array}$ \\
\hline 9 & $\begin{array}{l}\text { In the last month, how } \\
\text { often have you been } \\
\text { angered because of } \\
\text { things that were outside } \\
\text { of your control? }\end{array}$ & $\begin{array}{c}2 \\
(3.34)\end{array}$ & $\begin{array}{c}6 \\
(10)\end{array}$ & $\begin{array}{c}10 \\
(16.67)\end{array}$ & $\begin{array}{c}23 \\
(38.34)\end{array}$ & $\begin{array}{c}19 \\
(31.67)\end{array}$ \\
\hline 10 & $\begin{array}{l}\text { In the last month, how } \\
\text { often have you felt } \\
\text { difficulties were piling } \\
\text { up so high that you could } \\
\text { not overcome them? }\end{array}$ & $\begin{array}{c}3 \\
(5)\end{array}$ & $\begin{array}{c}1 \\
(1.67)\end{array}$ & $\begin{array}{c}12 \\
(20)\end{array}$ & $\begin{array}{c}25 \\
(41.67)\end{array}$ & $\begin{array}{c}19 \\
(31.67)\end{array}$ \\
\hline
\end{tabular}


Majority of the respondents agreed that they often perceived stress because of something that happened unexpectedly in the last month, they were unable to control the important things in their life, they were not confident enough to handle their personal problems or being unable to control irritations etc. Students often perceived stress when things were out of their control or they found it difficult to pile the things up because of uncontrollable situations.

The data gained by using this scale among the students of Pantnagar indicates that they stress a lot in different situations of the happenings. Almost forty percent of the female respondents reported that they feel nervous and stressed.

It can be concluded from the data survey that the majority of the male students experienced these stress parameters very often. Nearly forty two percent respondents reported that they felt stressed or nervous very often in the last month.

Next statement with which most of the respondents were agreed was that in the last month they felt they were on top of everything. With this statement a total of 43.34 per cent of the total 60 male respondents were agreed and marked it as fairly often.

The PSS assesses the appraisal of stress in day-to-day experiences and demonstrates excellent psychometric properties, with onedimensional structure (Roberti et al., 2006)

Stress is not a new phenomenon but is actually been experienced since the ancient times. Nowadays stress is responsible for more than $50 \%$ of all the illness which are occurring in humans. It produces numerous physiological and psychological symptoms which vary from individual to individual according to their situational factors.

\section{Findings}

Majority of the respondents agreed that they often perceived stress because of something that happened unexpectedly in the last month.

Some other problems were that they are unable to control the important things in their day to day life.

Some of the respondents reported that they were not confident enough to handle their personal problems.

It can be concluded from the perceived stress scale that in total of the 120 respondents, the statement which ranked 1 is that they often felt confident about the ability to handle their personal problems. The statement which ranked second was that they were not been able to control irritations in their life.

\section{References}

Bremner J D. Does stress damage the brain, Biol Psychiatry. 1999;45:797-805. [Google Scholar]

Colby J P, Linsky A S, Straus M A. Social stress and state-to-state differences in smoking-related mortality in the United States. Soc. Sci. Med. 1994;38:373-381.

Journal of Counseling Association, 9 (2006), pp. $135-147$

Lupien S J, McEwen B S, Gunnar M R, Heim C. Effects of stress throughout the lifespan on the brain, behaviour and cognition. Nat Rev Neurosci. 2009;10:434-445.

Lynch J W, Kaplan G A, Shema, M S. Cumulative impact of sustained economic hardship on physical, cognitive, psychological, and social functioning. New England Journal of Medicine.2012:398:1889 95.

Roberti, J. W., L. N. Harrington, E. A. Storch 
Further psychometric support for the 10 -item version of the perceived stress scale

Shahsavarani A M, Ashayeri H, Lotfian M, Sattari K. The effects of Stress on
Visual Selective Attention: The Moderating Role of Personality Factors. Journal of American Science. 2013; 9(6s): 1-16. 6.

\section{How to cite this article:}

Sangya Singh. 2021. Perceived Stress and its' Association with College Students. Int.J.Curr.Microbiol.App.Sci. 10(04): 323-328. doi: https://doi.org/10.20546/ijcmas.2021.1004.034 